\title{
A América do sul e o desenvolvimento sustentável: compromissos para a viabilidade do buen vivir ${ }^{1}$
}

\author{
South America and sustainable development: \\ commitments for the viability of good living
}

\author{
América del sur y el desarrollo sostenible: \\ compromisos para la viabilidad del buen vivir
}

Recibido: 18 de junio de 2015 - Revisado: 04 de noviembre de 2015 - Aceptado: 11 de abril de 2016

Neuro José Zambam²

Sérgio Ricardo Fernandes de Aquino ${ }^{3}$

\begin{abstract}
Resumo
O continente sul americano tem o compromisso com a afirmação da democracia e a sustentabilidade devido à sua integração cultural e à geografia ambiental. A partir da cultura indígena do buen vivir esta investigação tem como objetivo geral investigar como esta proposta pode trazer outras alternativas às propostas para um desenvolvimento sustentável na América do Sul não contempladas por teorias europeias ou norte-americanas. O método utilizado é o indutivo. No final, verificam-se significativas adversidades para se constituir uma vida digna pelo desenvolvimento sustentável na América do Sul, dentro do trinómio economia, justiça e política, pois qualquer perspectiva sobre o desenvolvimento que se procure como elemento de transformação não pode ser fundada num processo de desmedida exploração de pessoas e ecossistemas.
\end{abstract}

Palavras-chave:

Buen vivir, desenvolvimento, sustentável, economia, justiça, política.

\begin{abstract}
The South American continent has been committed to the affirmation of democracy and sustainability due to its cultural integration and the geography of the environment. From the indigenous culture of good living this research has as its general objective to investigate how this proposal can bring other alternatives to the demands for sustainable development in South America that are not covered by European or North American theories. The method used is deductive, along with the technique of bibliographical and documentary research. Finally, there are important adversities to be a worthy life for sustainable development in South America, in the trinomial economy, justice and politics. Any horizon in the development of being sought within the framework of transformation cannot be based on the infinite and unlimited process of exploitation of people and ecosystems.
\end{abstract}

\section{Keywords}

Good living, sustainable development, economy, justice, politics.

\section{Resumen}

El continente sudamericano se ha comprometido a la afirmación de la democracia y la sostenibilidad debido a su integración cultural y la geografía del medio ambiente. A partir de la cultura indígena de buen vivir esta investigación tiene como objetivo general para investigar cómo esta propuesta puede traer otras alternativas a las demandas para el
${ }^{1}$ Artigo revisão da literatura.

2 Pós-Doutor em Filosofia na Universidade do Vale do Rio dos Sinos.

Doutor em Filosofia pela PUCRS.

Mestrado da Faculdade Meridional

- IMED. Membro da Associação Nacional dos Programas de Pós Graduação em Filosofia (ANPOF). Professor e pesquisador da Faculdade Meridional - IMED de Passo Fundo. Brasil.

E-mail: neurojose@hotmail.com; nzambam@imed.edu.br.

${ }^{2}$ Doutor e Mestre em Ciência Jurídica pela Universidade do Vale do Itajaí. Mestrado em Direito do Complexo de Ensino Superior Meridional - IMED.

Professor e pesquisador da Faculdade Meridional - IMED da Faculdade Meridional. Membro do Conselho Nacional de Pós-Graduação em Direito (CONPEDI) e da Associação Brasileira do Ensino de Direito (ABEDI). Passo Fundo (RS), Brasil. E-mail: sergiorfaquino@gmail.com Para citar este artículo use: Zambam, N., \& Fernandes, S. (2016). A América do sul e o desenvolvimento sustentável: compromissos para a viabilidade do buen vivir. Civilizar Ciencias Sociales y Humanas, 16(31), 151-167. 
desarrollo sostenible en América del Sur que no estén cubiertos por las teorías europeos o norteamericanos. El método utilizado es deductivo, junto con la técnica de investigación bibliográfica y documental. Por último, hay las adversidades importantes para ser una vida digna para el desarrollo sostenible en América del Sur, en el trinomio Economía, Justicia y Política. Cualquier horizonte en el desarrollo de buscarse en el marco de la transformación no puede fundarse en el infinito e ilimitado proceso de explotación de las personas y los ecosistemas.

Palabras clave

Buen vivir, desarrollo sostenible, economía, justicia, política.

\section{Introdução}

No planalto andino, mama é a Virgem e mama é a terra e o tempo. Fica zangada a terra, a mãe terra, a Pachamama, se alguém bebe sem lhe oferecer. Quando ela sente muita sede, quebra a botija e derrama o que está lá dentro. A ela se oferece a placenta do recém-nascido, entre as flores, para que a criança viva; e para que o amor viva, os amantes enterram cachos de cabelos. A deusa terra recolhe nos braços os cansados e os maltrapilhos que dela brotaram, e abre-se para lhes dar refúgio no fim da viagem. Lá debaixo da terra, os mortos florescem (tradução própria, Galeano, 1999, p. 38).

A ideia de desenvolvimento sustentável é a premissa de uma vida qualitativa para o século XXI. Os desafios propostos por essa expressão exigem aos seres humanos outras perspectivas de vida e ações, as quais se necessitam de outras condições políticas, económicas, jurídicas, tecnológicas e culturais para a sua viabilidade. Paradoxalmente, insiste-se na Sustentabilidade como critério de progresso e, ao mesmo tempo, observam-se as maiores crises históricas vivenciadas desde a época da Grande Depressão em Nova Iorque no ano de 1929.

Quando o mundo se torna cada vez mais global, eficiente, veloz e capitalizado, a

América do Sul, a partir dos saberes ancestrais dos povos indígenas andinos (Bolívia e Equador), apresenta uma crítica sensata para os modelos de desenvolvimento sustentável que desejam um progresso em todos os tempos sob os mesmos moldes das expressões citadas no início deste parágrafo. Essa imagem é, no mínimo, contraditória.
Por esse motivo, procura-se identificar na proposição do buen vivir um outro caminho para que o desenvolvimento sustentável reconheça a necessidade da interação entre os seres humanos e o mundo natural, sem que haja qualquer forma de dominação ou exploração para atender aos interesses das pessoas. Este é o momento de rever os conceitos (im) postos para um mundo sustentável possível.

O significado de buen vivir aparece a partir da cultura dos povos indígenas Sumak Kawsay (Equador) e Aymara (Bolívia). Essa expressão denota "vida em plenitude" e manifesta-se como reivindicação desses povos contra o projeto económico e político liberal e neoliberal que marginaliza os seus modos de vida, e os priva das suas identidades históricas. Essas posturas agravam, cada vez mais, qualquer tentativa de emancipação dessas pessoas, seja na dimensão cidadã ou institucional. Por esse motivo, essa proposta é um clamor de vida da periferia ${ }^{1}$. A voz, antes silenciosa, agora, torna-se audível.

O buen vivir se tornou, no século XXI, a principal questão da política partidária., económica e jurídica, especialmente pelos seus protagonistas. Na representação indígena, percebe-se a atuação da Confederação de Nacionalidades Indígenas do Equador. (CONAIE), da Confederação Nacional de Organizações Campesinas, Indígenas e Negras (FENOCIN), da FEINE², da Confederação de Povos de Nacionalidade Kichwa do Equador (ECUARUNARI). Na dimensão institucional e académica, disseminase o pensamento de Alberto Acosta, Eduardo Gudynas, Páblo Davas, Luis Macas ${ }^{3}$ Magdalena Léon $^{4}$, entre outros. Por esse motivo, observase um forte compromisso social e institucional 


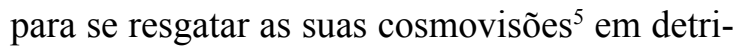
mento a esses projetos excludentes.

A partir desses argumentos, o critério metodológico utilizado para a investigação de abordagem e a base lógica do relato dos resultados apresentados reside no Método Induti$\mathrm{vo}^{6}$, cuja premissa menor é proposição andina do buen vivir e a premissa maior se manifesta pela aplicação desse saber como modelo de desenvolvimento sustentável. A técnica utilizada nesse estudo será a pesquisa bibliográfica ${ }^{7} \mathrm{e}$ documental. Para se estabelecer um acordo semântico mais claro para o leitor ou leitora, utilizar-se-á a categoria ${ }^{8}$ e o conceito operacional ${ }^{9}$.

$\mathrm{O}$ assunto de pesquisa formulado para este estudo pode ser descrito pela seguinte indagação: A proposição andina do buen vivir pode ser caracterizada como alternativa de desenvolvimento sustentável pela sua dimensão política, jurídica e econômica?

A hipótese para essa pergunta surge, inicialmente, como positiva, na medida em que se comprova a insuficiência do atual significado de desenvolvimento sustentável capaz de retratar outras condições de vida mais harmoniosa entre os seres humanos e não-humanos no continente sul-americano.

A proposição andina do buen vivir extrapola a lógica estabelecida pelos continentes americanos e europeus, cujo fundamento é a dinâmica antropocêntrica na busca por riquezas materiais, e estabelece novas dimensões comunitárias de vida e reconhecimento entre todos os seres que habitam essas terras do sul.

O Objetivo geral deste estudo é investigar como o buen vivir pode trazer outras alternativas às procuras por desenvolvimento sustentável na América do Sul não contempladas por teorias europeias ou norte-americanas.

Os objetivos específicos são: a) Esclarecer a importância histórica do buen vivir; b)
Definir o que é o buen vivir; c) Avaliar a necessária integração - e cooperação- entre os seres humanos e a Terra que os acolhe; d) Identificar a integração sul-americana como estratégia geopolítica de reconhecimento da natureza como ser próprio; e); f) Reconhecer as insuficiências políticas, jurídicas e económicas dos atuais modelos de desenvolvimento sustentável para se apresentar outra ideia de progresso.

Os referenciais teóricos escolhidos para esta pesquisa bibliográfica são expressos pelo pensamento de autores como Gudynas, Acosta, Veiga, Zaffaroni, Huanacuni Mamani, entre outros. Esses autores são importantes por que: 1) pertencem à América do Sul, ou seja, conhecem as suas adversidades e potencialidades. Para se desenvolver o objeto deste estudo, não se podem escolher autores europeus e/ou norteamericanos por desconhecerem, de perto, o modus vivendi deste continente; e 2) esclarecem como os temas do desenvolvimento sustentável e a proposta do buen vivir empreendem, de modo consistente, a disseminação de uma vida digna na América do Sul a partir do resgate de sua identidade cultural.

Percebe-se, ainda, a crítica necessária para que esses temas não se tornem discursos abstratos, incompatíveis com as realidades do mencionado continente, bem como não sejam uma publicidade governamental falaciosa incapaz de tornar possíveis as desejáveis transformações sociais, políticas, económicas, culturais e ambientais aos povos sul-americanos. Buscam-se, ainda, outras leituras, com diferentes percepções sobre o tema em estudo, para elucidar o(s) significado(s) e contexto(s) de determinadas categorias apresentadas neste estudo.

AAmérica do Sul não é diferente de outros locais no globo, cujos desafios são determinar os limites e o alcance da contribuição de valores locais aos mundiais. Procura-se identificar quais modelos sociais, políticos e económicos que conseguem solucionar as nossas dificuldades de 
emancipação e convivência herdadas do legado histórico de dominação e exploração.

É a partir do resgate das culturas ancestrais dos povos andinos que a proposta do buen vivir aparece cheia de significados para o Desenvolvimento Sustentável. Trata-se da contribuição sul-americana ao mundo de como a qualidade de vida não se refere apenas aos seres humanos e outras práticas - políticas, jurídicas e econômicas-permitem alcançar o objetivo debatido por todos os povos que é a sustentabilidade.

\section{O desenvolvimento sustentável e o buen vivir}

O principal desafio para um mundo sustentável no século XXI não se concentra, exclusivamente, na ideia de progresso, de crescimento económico, mas de como é possível estimular um desenvolvimento qualitativo para todos os seres vivos. Observese que a tónica do argumento não está em promover tão somente bem-estar para as "gerações presentes e futuras", como descreve o conceito operacional da categoria "desenvolvimento sustentável"10. O debate que se inicia procura, antes, distinguir essa expressão já mencionada de outra denominada sustentabilidade.

A Terra, na sua evolução, tenta, de modo entrópico ${ }^{11}$, estabelecer condições apropriadas para que a vida se desenvolva e se mantenha. Esse fenómeno, ao ser compreendido pelo ser humano, permitiu desenvolver um critério de sustentabilidade. Verifica-se que a expressão em estudo exerce influência para criar e estabilizar cenários adequados às diferentes manifestações vitais seja visíveis ou invisíveis, unicelulares ou pluricelulares.

Sob ângulo similar, o desenvolvimento sustentável refere-se às ações humanas empreendidas para promover vida qualitativa a todos os seres humanos, de modo intergeracional. Toda atitude descrita como "desenvolvimento sustentável" assemelhar-se-ia à virtude grega sophrosyné $e^{12}$.

Entretanto, sob esse nome - e outros, como a indiferente expressão "salvar o planeta" $" 13$ - tem-se promovido, bem como insistido, na postura do (desmedido) crescimento. A Natureza ainda é considerada objeto para que se satisfaçam todas as vontades humanas. Trata-se de um objeto no qual se explora indefinidamente. Qualquer modelo de desenvolvimento Sustentável precisa encontrar medidas possíveis (políticas, culturais, jurídicas) para que haja progresso sem, contudo, se fixar na ideia (obsessiva) do crescimento, especialmente o económico.

Nessa linha de pensamento, indagase: Quando se fala sobre desenvolvimento sustentável na América do Sul, sobre o que estamos debatendo? A referida expressão deve ser entendida a partir da realidade dos povos indígenas do mencionado território. Essa afirmação não denota, em momento algum, qualquer retrocesso civilizacional, não significa viver uma "vida tribal", mas reconhecer quais são as contribuições dessas culturas para se elaborar, interpretar, desenvolver, articular e executar atitudes - individuais, coletivas e institucionais - capazes de mitigar as misérias humanas e favorecer uma vida digna em plenitude ${ }^{14}$.

Percebe-se, a partir da afirmação anterior, como a expressão "desenvolvimento sustentável" implica numa dupla tarefa: a) identificar aquilo que se torna indispensável para manter a vida a todos os seres vivos; b) reconhecer e respeitar os ciclos regenerativos do mundo natural, sem que haja uma interferência humana excessiva. Essa é a epifania que surge pela descoberta da Sustentabilidade na ação dos homens e mulheres. As duas situações sinalizam como o avanço político, jurídico, económico e ambiental na América do Sul se torna uma necessidade na constituição de uma identidade própria. 
No entanto, o desenvolvimento sustentável "não indígena" 15 é incapaz de esboçar as características culturais, as dificuldades regionais, as peculiaridades ambientais deste continente. Trata-se, no pensamento de Acosta e Gudynas (2011a, p.72), de um mau desenvolvimento que enseja o mau viver pautado pela eficiência, pelo consumo, pela alta industrialização e a incapacidade humana de enxergar os limites do mundo natural para garantir a sua (indefinida) permanência na terra. A crítica para esses modelos pouco sustentáveis e nada includentes está na proposta andina do buen vivir.

A filosofia andina do buen vivir representa essa cumplicidade entre seres humanos e a natureza, o que afeta, de modo significativo, a elaboração de sua política, de suas ações econômicas e jurídicas. A postura antropocêntrica, centrada apenas no ego, esvazia o local daquilo que é comum a todos e forma a sua unidade. Procura-se, a partir dessa compreensão, estabelecer modos responsáveis de mitigação das desigualdades ${ }^{16}$ e a promoção do aperfeiçoamento humano, por um lado, e o respeito à natureza como "ser próprio", por outro. Caso contrário, e a partir do intenso estilo devida predatório escolhido, não haverá qualquer avanço civilizacional, com respeito mínimo aos direitos humanos e dignidade humana, capaz de justificar a convivência nessas terras.

Construir um paradigma identitário a partir da comunidade e da cosmovisão originária dos povos indígenas traz o estímulo à responsabilidade e resgata essa proposta de se viver bem (buen vivir) entre todos os seres vivos que habitam este continente sul-americano. $\mathrm{Na}$ Bolívia, a expressão é Suma Qamaña ${ }^{17}$ do povo indígena Aymara. No Equador, Sumak Kawsay, originário do povo indígena Kichwa ${ }^{18}$. Vejamse as palavras de Huanacuni Mamani (2010):

Os povos indígenas originários estão trazendo algo de novo (para o mundo moderno) às mesas de discussão, sobre como a humanidade deve viver de agora em diante, já que o mercado mundial, o crescimento económico, o corporativismo, o capitalismo e o consumismo, são produto de paradigma ocidental, são a diversos níveis as causas profundas da grave crise social, económica e política. Perante estas condições, a partir das diferentes comunidades de povos originários de Abya Yala, nós dizemos que, na realidade, se trata de uma crise de vida. Debaixo da influência deste momento histórico, toda a sociedade está imersa em tempos de mudança e por outro lado, todos e cada um dos seres humanos são co-responsáveis, como geração, de ajudar a estas mudanças, sustentados em novos (ainda que antigos) paradigmas de vida, em vez dos individualistas e homogenizadores que estão causando tanto prejuízo nas relações interpessoais e sociais (p. 6).

Essa cosmovisão proveniente da cultura indígena andina revela-se pela expressão Pacha. Para Huanacuni Mamani, essa palavra se decompõe em "Pa" - a qual significa "dois" - e "Cha", que significa "Força". Pacha" pode ser descrita como a união de duas forças cósmico-telúrica ${ }^{20}$, ou seja, a energia que flui por toda a Terra - seja celeste ou terrestre - e a regenera. Trata-se da compreensão do mundo, cuja energia transborda no tempo e espaço.

O conceito dessa última palavra citada é diferente para o ocidente e para a cultura Andina. No primeiro, o tempo é linear, progressivo $^{20}$. Passado, presente e futuro são distintos. No segundo, o tempo é circular, ou seja, os referidos períodos temporais são contínuos e fundem-se no final, como descreve Huanacuni Mamani (2010, p. 72). Nessa linha de pensamento, o modelo (parasitário) europeu ou norte-americano de consumo, de busca pelo capital, de eficiência a qualquer custo, mostramse contrários a esse cenário de inclusão da Natureza e o respeito aos seus próprios ciclos de vida.

Pacha rememora a necessidade de se sentir o buen vivir (viver bem) em todos os momentos, de compreendê-lo e exercitá-lo e não simplesmente adiá-lo para o momento futuro. $\mathrm{Na}$ cosmovisão andina, tudo tem vida 
(Huanacuni-Mamani, 2010, p. 72). O tempo, portanto, precisa dialogar entre Passado, Presente e Futuro. Eis a epifania fundamental: a vida é omnipresente em todos e tudo e se desdobra com múltiplos significados.

A proposta do buen vivir não pode ser pensada nos padrões clássicos de modelos, capazes de responder, atemporalmente, às nossas angústias. Os saberes tradicionais dos povos andinos indicam que a busca pelo "Viver Bem" é algo sempre em construção. Não se trata de um saber fechado, incapaz de se movimentar, de se modificar, de se auto-avaliar nos diferentes locais e tempos.

É por esse motivo que Acosta e Gudynas (2011a, p. 81) sinalizam: o buen vivir não é um desenvolvimento sustentável alternativo, mas uma alternativa ao desenvolvimento sustentável, o qual, hoje e segundo a sua definição a partir dos países desenvolvidos, não conhece os limites de exploração da natureza ou do ser humano. Essa é a crítica que a mencionada proposta realiza contra os tipos de desenvolvimento que desprezam as relações de complementaridade entre as pessoas e o mundo que as cercam. Ao não se reconhecer esses elos, é improvável que o adjetivo «sustentável» se torne um projeto de cumplicidade dialogal e histórica, mas petrifica e torna vazio seu propósito.

Percebe-se que a busca pelo "viver bem" consubstancia um princípio o que pode ser descrito na seguinte expressão: "somos um em todos e todos em um"22. Vida em plenitude ${ }^{23}$ : essa é a preocupação de uma proposta de desenvolvimento sustentável ${ }^{24}$, cujo tempo e o espaço se procuram identificar-nos diferentes diálogos entre os sujeitos humanos e não humanos. Os esforços na busca deste objetivo comum são trans-fronteiriços e unem dimensões locais, regionais nacionais, continentais e globais para resgatar o único local que acolhe a vida no seu sentido mais amplo: a Terra.

A partir desse cenário, ressalta-se a síntese sobre o buen vivir no pensamento de
Huanacuni Mamani (2010): "Vivir bien, es la vida en plenitud. Saber vivir em armonía y equilibrio; en armonía con los ciclos de la Madre Tierra, del cosmos, de la vida y de la historia, y en equilibrio con toda forma de existencia en permanente respeto" (p. 32). $E$ a partir dessa concepção, dessa con-vivência que o desenvolvimento sustentável se afirma como identidade global do século XXI. Sob o tríplice significado proposto para este estudo, inicia-se a compreensão do "Viver Bem" pela sua dimensão política.

\section{Buen vivir e a política}

Não basta reconhecer a importância de este saber andino como alternativa ao desenvolvimento sustentável, mas, também, instituir ações que estimulem o fomento e a educação à política do "viver bem", especialmente politicas públicas. Nessa linha de pensamento, o fundamento primeiro de uma dimensão política do desenvolvimento sustentável a partir do buen vivir é a vida comunitária.

A sabedoria de Pacha, a qual conduz a viabilidade da citada proposta, não se assemelha àqueles critérios de organização política e econômica europeia que se observa desde a queda do Muro de Berlim em 1989. A crise civilizatória ${ }^{25}$ vivenciada desde a época mencionada demonstra como os projetos socialistas ou capitalistas não conseguiram (e não conseguem) manter condições de vida sustentável para todos, tampouco reconhecer a importância da natureza como "sujeito próprio". Sob o nome de desenvolvimento sustentável, verifica-se ações políticas camaleônicas no sentido de não propugnar o interesse comum, mas interesses setoriais e eleitorais, principalmente nos ambientes nacionais.

A vida comunitária pouco se assemelha à proposição de uma convivência fundamentada pelas bases teóricas e políticas da sociedade. Nesse último espaço mencionado, observa-se que os interesses são sintetizados pelo comando 
da voz estatal. A cumplicidade e proximidade entre as pessoas são diluídas pela autoridade, seja burocrática, legal ou intelectual. Não resta outro destino aos "cidadãos" senão cumprir, exaurir nos exatos limites semânticos as disposições enunciadas por um «contrato social" ${ }^{26}$.

Sob ângulo diferente, a identificação daquilo que é comum para todos, fomenta a sua unidade vivencial, ou seja, sujeitos humanos e não-humanos constituem o seu modus vivendi ao compreenderem seus limites e possibilidades. Toda a ação política, especialmente institucional, a partir da proposta do buen vivir amplia os espaços de decisão para uma convergência dialogal entre todos a fim de se encontrar aquilo que se torna indispensável para a qualidade de vida humana e não-humana.

No espaço comunitário, estimulam-se as responsabilidades as quais não se esgotam pelas vias da autoridade, do contrato ou da lei. Ao contrário, a vivência, o compartilhar algo junto com o Outro fomenta diferentes afetos, diferentes trabalhos, diferentes experiências os quais tornam o con-viver um ambiente próprio de resgate ao excluído, ao "esquecido", aos campesinos, ao estrangeiro, ou seja, todos os que, antes, num projeto civilizacional europeu ou norte-americano, não eram vistos, não eram lembrados ou sequer convidados para formarem esse mosaico vital na América do Sul ${ }^{27}$.

O governo do Equador (2013), sob esse argumento, fixou 12 (doze) objetivos para implementar, até o ano de 2017, a política nacional do buen vivir, os quais inspiram a busca por outros critérios para a crise mundial ${ }^{28}$. Para o mencionado país, é necessário:

Objetivo 1: "Consolidar o Estado democrático e a construção do poder popular", estabelecendo as políticas e as linhas estratégicas necessárias para implantar o processo de transformação do Estado e fortalecer o poder popular e do cidadão.
Objetivo 2: "Atingir a igualdade, a coesão, a inclusão e a equidade social e territorial, na diversidade". Objetivo 3: "Melhorar a qualidade de vida das populações".

Objetivo 4: "Fortalecer as capacidades e potencialidades da cidadania".

Objetivo 5: "Construir espaços de encontro comum e fortalecer a identidade nacional, as identidades diversas, a plurinacionalidade e la interculturalidade".

Objetivo 6: "Consolidar a transformação da justiça e fortalecer a segurança integral, em estrito respeito pelos direitos humanos".

Objetivo 7: "Garantir os direitos da natureza e promover a sustentabilidade ambiental territorial e global".

Objetivo 8: "Consolidar o sistema económico social e solidário, de forma sustentável".

Objetivo 9: "Garantir trabalho digno em todas as suas formas".

Objetivo 10: "Impulsionar a transformação da matriz produtiva".

Objetivo 11: "Assegurar a soberania e eficiência dos sectores estratégicos para 1 transformação industrial e tecnológica".

Objetivo 12: "Garantir a soberania e a paz, aprofundar a inserção estratégica no mundo e a integração latino-americana" (pp. 81-83).

Esses objetivos, contudo, não favorecem, muito menos consolidam, um cenário mais otimista ao desenvolvimento e difusão do buen vivir. $\mathrm{O}$ planeamento para o ano de 2017 contém objetivos ousados, porém pouco eficazes porque não se compreende as raízes dessa proposta para uma vida digna. Veja-se: 2017 não é um tempo longínquo, ao contrário, tem menos de 365 (trezentos e sessenta e cinco) dias para se conseguir. Quais são as mudanças mais evidentes que se conseguiu por meio desse plano? Poucas.

Não obstante se reconheça a importância dos seus princípios, o programa tornase débil devido ao seu caráter panfletário aos governos ditos progressistas dessas regiões. Torna-se difícil de se verificar uma correspondência de atitudes entre o Estado Central, os governos 
descentralizados e as comunidades indígenas capazes de tornar factível esses objetivos porque os interesses são opostos. Na dimensão da realpolitik, vigora, sim, o oposto daquilo que foi descrito como fonte de orientação à viabilidade do buen vivir. Vive-se, de fato, numa república dos bons sentimentos ${ }^{29}$.

$\mathrm{Na}$ verdade, o que se insiste a partir desse plano nacional não é o paulatino esforço comum para tornar o buen vivir uma alternativa ao desenvolvimento sustentável, esclarecendo a sua importância a partir de condutas individuais, coletivas e institucionais. Ao contrário, o uso propagandístico desta cultura ancestral apenas esconde, ainda, um modelo de vida que se pauta pela exploração de tudo e todos. Por esse motivo Acosta (2013) adverte:

A lista de incongruências dos governos progressistas, tanto a nível nacional como nos territórios descentralizados, declaram intenções distintas entre os mandatos constitucionais e a "real politik" de formas de continuidade de consumismo, refletindo também o uso propagandistico. Basta ver a quantidade de documentos e programas oficiais que anunciam o objetivo do Buen Vivir como orientação publicitária. Como exemplo, projetos municipais para melhorar asestradas são apresentados como se isso se tratasse do Buen Vivir, com cidades construídas com base na cultura do automóvel e não dos seres humanos. Igualmente, enquanto se continua o extrativismo nas grandes minas e se amplia a exploração pretrolifera, implantam-se programas governamentais apelidados como de "Buen Vivir". Todo isto representa un sumak kawsay propagandístico e burocratizado, com falta de conteúdo, reduzido à condição de produto final (p. 67).

Outro ponto fundamental $\grave{a}$ certa instabilidade desse Plano Nacional é o desequilíbrio entre os critérios de mensuração e o cumprimento dos objetivos. Existem mais finalidades que instrumentos capazes de acompanhar as mudanças que ocorrem no território equatoriano. Esse planeamento afirma que é necessária uma nova métrica multidimensional, integradora e holística a qual supere os limites do desenvolvimento e integre a preservação da natureza, a necessidade da sustentabilidade e as realizações humanas (República do Equador, 2013, p. 29).

No entanto, observa-se que essa métrica, até o momento presente, não existe. É possível que no ano 2017 essa ferramenta apareça no intuito de cumprir os objetivos postos tanto nesse planeamento, quanto na descrição do buen vivir dentro da Constituição do Equador. Na medida em que não se dispuser deste instrumento a fim de corroborar as melhorias enunciadas por este plano nacional, intensificam-se mais e mais a exploração do mundo natural ${ }^{30}$, de um lado, e os altos índices de baixa distribuição das riquezas, da mitigação das desigualdades, do combate às atitudes racistas, entre outros.

Cita-se como exemplo a preservação do Parque Yasuni. O governo de Rafael Corrêa viola, de modo reiterado, este local que abriga diferentes espécies de fauna e flora a fim de garantir outros objetivos como a eliminação da miséria. Vende-se, nesse caso, a Natureza, pelo preço mais alto possível, descaracterizando, na íntegra, a proposta do buen vivir, especialmente naquilo que prevê a Constituição do Equador no seu artigo 71, ou seja, os Direitos da Natureza, conforme já denunciava Gudynas (2014, p. 159).

Toda essa mudança incitada pelo buen vivir deve ser acompanhada pela insistência para uma convivência digna e harmónica entre homem e natureza neste século XXI. Esse é um dos principais nomes para se conferir sentido à expressão desenvolvimento sustentável. Por esse motivo, as múltiplas cosmovisões, cada uma pelo seu sentido de complementaridade, convergem esforços para uma Estética da Alteridade, ou seja, de reconhecimento ao Outro como elemento constitutivo dessas relações, as quais não podem ser disseminadas como simples propagandas governamentais, mas verdadeiro modus vivendi et actuandi. 
A vida torna-se uma bela obra de arte constituída, diariamente, a cada som, palavra, gesto, cumplicidade de emoções ${ }^{31}$. Esse cenário é (quase) inexistente dentro de uma sociedade pautada pela eficiência, pelo consumo desmedido, pelas responsabilidades enunciadas pelas leis, pela exclusão de todos que não se adequam a esse cenário mencionada e descrito, para muitos, como qualitativo. Esse é o resgate (incompreendido).

Sob igual critério, as políticas públicas originárias da proposta do buen vivir conduzem ao desenvolvimento sustentável na medida em que exige dos diversos sujeitos, dos movimentos sociais, das associações e organizações, das instituições públicas, das empresas, a sua participação para se conjugarem esforços na distribuição das riquezas, dos trabalhos, da saúde, da educação, dos alimentos, dos territórios, da água, da energia, entre outros ${ }^{32}$.

$E$ E a partir desta concepção comunitária que não se sobrepõem interesses de uns pelos outros, especialmente os governamentais, mas se encontram respostas, se encontram ações para que não hajam excessos positivos ou negativos, seja para as pessoas ou para a Natureza. Por esse motivo, é necessário meditar as palavras de Huanacuni Mamani (2010) sobre o que deve contemplar as políticas públicas a partir do "viver bem":

Criação de comunidades produtivas: impulsionar e promover a rearticulação comunitária, tanto no campo como nas cidades. Comprar e criar semente sãs, sem alteração genética: De acordo com o princípio do Qolqa44 deve-se criar um centro ou instituto de produção natural de sementes e recuperação das diferentes variedades.! Criar alianças complementares estratégicas entre comunidades e o Estado e a comunidade, entre empresas privadas, Estado e as comunidades.! Os Estados devem garantir primeiro as necessidades internas (mercado interno) e depois exportar, não sómente num sentido só comercial mas sim buscando relações em função do princípio do ayni, ou seja complementarmo-nos uns aos outros países, sempre resolvendo primeiro as necessidades internas.! Implementar créditos às comunidades.! Produzir alimento tendo em conta a dimensão espiritual.! Promover uma alimentação saudável, que não significa necessariamente "estômago cheio" (tradução própria, p. 56).

A dimensão política do buen vivir inaugura uma outra percepção para se distribuir bens e serviços às pessoas, bem como a melhoria da sua qualidade de vida. A natureza é, agora, uma parceira dialogal e não mais um objeto a ser explorado de modo indefinido para atender às procuras obsessivas do progresso e crescimento económico. $\mathrm{O}$ respeito e reconhecimento aos seus ciclos de vida exigem outras ações, estruturas e planeamentos a fim de preservar os seus benefícios para todos os seres vivos que ali habitam e encontram as condições necessárias para a sua manutenção diária. Observa-se uma "visão ecocêntrica" ${ }^{33}$ na qual se expressa, ainda, na dimensão jurídica.

\section{Buen vivir e a justiça}

Toda expressão comunitária, que estimula novas responsabilidades, modifica a relação de dominação entre os seres humanos e a natureza, descoloniza saberes e amplia variadas e diferentes cosmovisões a fim de tornar o desenvolvimento sustentável um projeto em permanente inquietação e metamorfose, deve ser assegurada por instrumentos que preservam condições de exercício e reivindicação desses cenários quando forem suprimidos da vida de todos os dias ou não oportunizados pelas ações quotidiano das pessoas com a natureza e das ações governamentais entre os sujeitos que compõem uma organização social local ou global.

A proposta do buen vivir reivindica, segundo o pensamento de Huanacuni Mamani (2010, p. 46-47), um direito natural ancestral comunitário $^{34}$ que não se limite a aplicar castigos, nem reconhece que o Direito se destina somente àqueles que detém bens patrimoniais ou capital (ilimitado), tão pouco se revela pela 
sua autoridade coercitiva a fim de garantir o mínimo de organização entre as pessoas para se ter uma convivência mais harmoniosa.

Ao contrário, a dimensão jurídica do buen vivir aposta na liberdade, responsabilidade, respeito, reciprocidade e solidariedade ${ }^{35}$ na interação das pessoas e a natureza. Essa proximidade, típica dos povos indígenas, desvela o cuidado e novas sensibilidades como critérios de integração, os quais se podem observar, também, em outros documentos internacionais, como a Carta da Terra, a Declaração das Nações Unidas sobre os Direitos dos Povos Indígenas, a Convenção 169 da Organização Internacional do Trabalho (OIT), entre outros. Na medida em que se oportuniza essa dimensão vivencial, apesar de todas as suas dificuldades práticas, verifica-se, nesses territórios, a procura secundária pela preservação desses pressupostos ao "viver bem"36, pois, nas palavras do mencionado autor (2010):

Ao contrário o sistema jurídico comunitário precede a vida é o respeito à liberdade. Perante a quebra da harmonia comunitária, não recorre a práticas punitivas mas a que toda a comunidade ajude para que a existência ou o ser humano que saiu deste equilíbrio e harmonia volte a eles, atribuindo-lhes tarefas de trabalho para devolver-lhes a sensibilidade e a compreensão de que a vida é conjunta e a necessidade de complementação e cuidado entre todos. A premissa para os povos indígenas originários é a comunidade sobrepondo-se ao individual; a comunidade é o pilar essencial de toda a estrutura organizaria da vida, que não se refere simplesmente à coesão social mas à estrutura e percepção da vida que vai mais além que os seres humanos e que se relaciona com toda a forma de existência numa comumunidade de inter-relação e interdependência recíprocas (tradução própria, p. 47).

A força da interdependência entre as várias comunidades (artificiais ou naturais) demonstra o seu caráter de indispensabilidade à manutenção da vida para todos os seres vivos. Por esse motivo, um outro modelo jurídico, caracterizado por essa perspectiva comunitária, precisa atender às (novas) expressões de convivência a fim de estimular um significado genuíno para a expressão desenvolvimento sustentável.

É nessa linha de pensamento que a proposta do buen vivir traz novas perspectivas na medida em que admite a natureza como "ser próprio" ou, em outras palavras, como "sujeito de direitos" nas constituições da Bolívia e Equador $^{37}$. Não se trata tão somente de expressar, nesses ambientes jurídicos, a cultura e a ética das comunidades andinas, mas de reconhecer a importância jurídica do mundo natural como parceiro ao desenvolvimento e manutenção de todos os seres vivos. Não se admite mais aquela interpretação, como se observa na leitura do artigo 225 da Constituição Federal Brasileira, da natureza como "património" ou "bem" destinado a manter (sómente) a presença humana de modo indefinido na terra.

A leitura não pode ser mais antropocêntrica, mas ecocêntrica, pois a aplicação de um direito natural ancestral comunitário reivindica a comunhão vital entre os seres vivos que habitam diferentes lugares no território terrestre. Essa acepção reforça como a biodiversidade deve ser compreendida pelas suas próprias características, inclusive no planeamento da ocupação humana.

As consequências desse novo tratamento jurídico para a natureza, descrita na sabedoria andina como Pachamama ${ }^{38}$, estimula novos mecanismos nas constituições da Bolívia e Equador que garantam uma participação trans-fronteiriça de todos na sua preservação, manutenção e cuidado. A responsabilidade nacional tornou-se clara perante algo que favorece a qualidade de vida para todos os seres vivos os quais dependem das benesses trazidas pela fauna e flora do continente sul-americano. Veja-se, por exemplo, o enunciado do artigo 71 da Constituição do Equador (2008):

[...] A natureza o Pachamama, onde se reproduz e realiza a vida, tem direito a que se res- 
peite integralmente a sua existência e a manutenção e regeneração dos seus ciclos vitais, estruturas, funções e processos evolutivos. Toda pessoa, comunidade, povo ou nacionalidade poderá exigir da autoridade pública o cumprimento dos direitos da natureza. Para aplicar e interpretar estes direitos respeitarse-ão os princípios estabelecidos na Constituição, no que estejam de acordo. O Estado incentivará as pessoas singulares e jurídicas, $\mathrm{e}$ as instituições, para que protejam a natureza, e promoverá o respeito por todos os elementos que formam um ecosistema.

Sob idêntico argumento jurídico, os artigos $33^{39}$ e $34^{40}$ da Constituição da Bolívia asseguram a proteção da natureza como indispensável à manutenção da vida no seu sentido mais amplo e procuram outras vias de compreensão comunitária sobre os cuidados e responsabilidades necessárias para se identificar o mundo natural não como objeto, mas "ser próprio", com "vida própria" que não se destina à instrumentalização dos (infinitos) desejos humanos. É a partir desse vínculo comunitário vital que o Direito se transforma para manter uma ordem social, cuja premissa não é exclusivamente a lei, mas a cumplicidade, a comunhão e cuidado entre todas as vidas.

O contrato social, celebrado por Rousseau, não consegue atingir essa nova condição protetiva porque não incluiu a natureza - ou Pachamama - como sujeito que participa juntamente com os seres humanos na manutenção desta nossa morada comum. Para que os efeitos desse pacto tragam significativas mudanças ao nosso momento presente, é necessário a sua complementação com o "contrato natural" um contrato cujo fundamento são as relações amistosas que evitam o surgimento e a proliferação de parasitas. [...] O contrato natural é escrito sob a premissa do amor, em todas as partes do mundo» (Aquino, 2014a, p. 205).

A relação simbiótica entre todos os seres vivos denota um contrato cujo fundamento ocorre pelo seu caráter simbiótico. Se existe uma preocupação com as diferentes comunidades vivas, a justiça a que se refere deve ser ecológica e não destinada tão-sómente a preservar as "presentes e futuras gerações". Não! Todas essas evidências jurídicas não apenas denotam uma mudança na ideia do contrato que governa essa pluralidade de comunidades, como a justiça precisa incluir a natureza para mitigar os excessos que a deterioram.

$\mathrm{O}$ contrato natural e a justiça ecológica ${ }^{42}$ esclarecem como os saberes andinos, aos poucos, inauguram uma alternativa sulamericana de desenvolvimento sustentável por meio dos direitos da natureza ${ }^{43}$. A partir dessa linha de pensamento, junto às dimensões política e jurídica, a económica, também, precisa sofrer as angústias de uma metamorfose para que haja vida em plenitude para todos nessa região continental.

\section{O buen vivir e a economía}

"Viver bem" não significa viver melhor. Essa distinção é necessária para se compreender como o saber andino visa tornar eficaz a ideia de desenvolvimento sustentável a partir do domínio económico. A proposta da segunda expressão citada - "viver melhor" reproduz as desigualdades promovidas pela alta atividade industrial, pelo trabalho excessivo (e, muitas vezes, análogo à condição escrava), pelo consumo desmedido de pessoas, animais e plantas, pela ganância difundida como critério de organização social. Esse é o cenário desejável pelo progresso caracterizado por um crescimento económico ilimitado ${ }^{44}$.

A proposta do buen vivir não despreza as articulações sócio-políticaseconómicas enfatizadas pela Globalização. Ao contrário, os resultados advindos dessa práxis que entende o mundo como um "grande mercado", acentuam as desigualdades históricas na América do Sul, já descritas e vivenciadas pelo seu caráter colonial. É nessa linha de pensamento que a 
citada cultura ancestral reivindica outro modo de vida, cuja Dignidade não seja violada habitualmente. Será que atual crise financeira, pergunta Acosta (2013, pp. 24-25), permite a constituição de outra organização civilizatória, a qual consiga reconstruir - desde que potencialize o local e o próprio - outros tipos de Estados nacionais que, ali, consiga elaborar espaços democráticos globais? A resposta parece positiva: $\mathrm{O}$ alcance do buen vivir, ainda que com significativas dificuldades, pode vir a ser global, pode se projetar como expressão de utopia capaz de enfrentar, propositivamente, essa alienação mundial causada por uma ideia de progresso, cujo alicerce está na permanente acumulação de bens materiais e tecnológicos. Nesse caso, não existem pessoas, cidadãos ${ }^{45}$, mas apenas, consumidores.

Os modelos de desenvolvimento sustentável partem da premissa do capitalismo ${ }^{46}$ e suas vertentes para "preservar o meio ambiente" (como se observa pela economia verde). Na proposta do buen vivir a insistência no capital e sua aquisição criam cenários de exclusão e miséria quando não oportunizam condições para, de um lado, se distribuir entre as pessoas trabalho, saúde, educação, lazer, alimentação e, por outro, o reconhecimento dos limites de exploração da vida natural por meio de seus ciclos regenerativos, bem como da preservação das espécies que dependem da flora, dos rios, das montanhas para manter uma vida equilibrada, sem que haja interferência excessiva da ação humana ${ }^{47}$.

A busca por uma vida comunitária equilibrada não é tarefa fácil. Exige-se que outras condições de fomento e melhoria da Economia possibilitem a concretização dessa interdependência entre os sujeitos humanos e não-humanos. Por esse motivo, além de não se compatibilizar com os cenários históricos e culturais da América do Sul, os atuais modelos (camaleônicos) de desenvolvimento sustentável, a partir da economia capitalista, inviabilizam os objetivos para que haja a amplitude de solidariedade, respeito, reciprocidade e responsabilidade entre as diferentes comunidades sul-americanas. Verificam-se como as palavras de Huanacuni Mamani (2010) precisam ser refletidas:

Na visão do viver bem, a preocupação central não é acumular. $\mathrm{O}$ estar em permanente harmonia com tudo convida-nos a não consumir mais do que o eco-sistema pode suportar, a evitar a produção de resíduos que no podemos absorver com segurança. Nos Incita-nos a reutilizar e reciclar tudo o que usamos. Nesta época de procura de novos caminhos para a humanidade, a ideia do 'buen vivir' tem muito a ensinarmos. O viver bem não pode conceberse sen a comunidade. Aparece para contradizer a lógica capitalista, o seu individualismo inerente, a monetarização da vida em todas as suas áreas, la desnaturalização do ser humano e a visão da natureza como "um recurso que pode ser explorado, uma coisa sem vida, um objeto a ser utilizado (p. 33).

Não se pretende abolir as ações económicas, mas submetê-las a outros critérios que não privilegiem a acumulação desmedida de bens, mas por outro lado amplie efomente condições de distribuição a fim de que todos tenham vida em plenitude ${ }^{48}$. Transformar as relações humanas com o mundo natural em "mercados" ou exigir que o Estado resolva seus conflitos apenas por indicadores mercantis ${ }^{49}$ ou económicos é empobrecer, de modo demasiado, a pluralidade de cenários, pessoas, tempos e locais os quais trazem, também, outros horizontes para tornar essa cumplicidade mais viável e visível para todos.

O progresso ilimitado pelo crescimento económico infinito evidencia, historicamente, as diferentes crises e catástrofes enunciadas todos os dias pelos diferentes canais de mídia e comunicação. É preciso, a partir da proposta do buen vivir, ter coragem para se insistir no desejável progresso sem que haja tão-somente crescimento, mas o seu oposto: decrescimento. Esse é o caminho apropriado para um desenvolvimento sustentável económico ${ }^{50}$ na América do Sul. 
Toda ação económica - nas suas diferentes atividades de produção, extração, comercialização, transformação - precisa de energia. $O$ decrescimento ${ }^{51}$ ensina, pela segunda lei da termodinâmica, que toda perda energética não se renova. Por esse motivo, evidencia-se a finitude do mundo natural e humano para constituir uma vida equilibrada. Não se pode admitir que o desenvolvimento sustentável tenha como único critério de melhoria o permanente crescimento $^{52}$. Outras oportunidades, outras respostas deverão vir das práticas económicas locais a fim de viabilizar, cada vez mais, um "viver bem" e não uma procura parasitária para se "viver melhor".

A ênfase numa economia comunitária ${ }^{53}$ destaca a necessidade do decrescimento sem que haja o desaparecimento das relações económicas. Ninguém, nem os seres humanos, podem se classificar como superiores às outras formas de vida. É a partir dessa compreensão que a Natureza não se torna objeto ${ }^{54}$ da livre exploração económica. Planeia-se o uso adequado de todas as energias para se estimular e indagar os objetivos do desenvolvimento sustentável. Nessa linha de pensamento, as palavras de Cechin (2010) são necessárias para se compreender as diretrizes para uma economia a partir da ecologia e decrescimento:

[...] Desenvolvimento requer energia. E ela é que liga os desafios da sustentabilidade ambiental com as dimensões social e económica do desenvolvimento. [...] Não é possível, portanto, falar de desenvolvimento sustentável sem aludir à base energética na qual se baseou o desenvolvimento a partir da Revolução Industrial. Então, a questão fundamental é saber se os humanos podem coletivamente perceber a magnitude do problema atual e procurar as soluções necessárias (pp. 180-181).

A proposição do buen vivir traz uma crítica necessária ao modus vivendi de um cenário sul-americano pautado pela economia capitalista. As acentuadas desigualdades, os serviços precários, a relação de dominação com o mundo natural, o desperdício energético das diferentes comunidades de seres vivos, a eliminação cultural da proximidade, respeito e solidariedade causam as múltiplas crises vivenciadas na dimensão local. Tratam-se de situações que não são resolvidas por respostas superficiais diante de sua complexidade. Sob idêntico argumento, é inviável pensar em desenvolvimento sustentável no domínio económico sem que haja uma profunda modificação na relação dos seres humanos com a natureza.

Quando se percebe a importância do mundo natural como um parceiro para a melhoria de vida a todos os seres vivos, não se pode mais admitir as vias do progresso pelo crescimento desmedido e ilimitado para satisfazer apenas interesses setoriais. É necessário modificar o modus operandi dos procedimentos económicos para outros mais viáveis, nos quais se possa saber usar de modo adequado todas as energias envolvidas, sejam as naturais ou artificiais.

Na medida em que se criam mecanismos os quais favorecem o melhor uso energético dos seres vivos em diferentes atividades, observase os desafios próprios do buen vivir para superar a sua fragilidade histórica e iluminar novas perspectivas para a vida no globo $^{55}$. A tríplice caracterização do "viver bem" pela sua dimensão política, jurídica e económica demonstra sua face utópica a qual não é abstrata, mas concreta ${ }^{56}$ e que se renova a cada interação e compreensão entre os diferentes locais, culturas, seres e sensações provocadas por essa cumplicidade, inicialmente, continental. Esse é o desenvolvimento sustentável próprio da América do Sul.

\section{Conclusão}

Nenhum desenvolvimento sustentável se funda na exploração, seja de seres humanos ou do mundo natural. Na dimensão da linguagem, essa postura seria entendida como oxímora. 
A referida expressão - desenvolvimento sustentável - tem significado mais enraizado, mais profundo quando a sua matriz de compreensão não reside apenas no humano, mas na teia da vida. É a partir dessa condição que a proposição do buen vivir não se torna uma resposta pronta para as adversidades sulamericanas, mas uma alternativa - de alcance global - a qual surgiu da periferia a partir das intensas de exclusão, de abandono.

Como fundamento do desenvolvimento sustentável, o buen vivir dissemina uma atitude de reconhecimento e cuidado na manutenção dos seres vivos que compõem a cadeia vital na medida em que as pessoas se indagam como é possível buscar o desenvolvimento sem que haja uma dependência acentuada ou obsessiva pelo crescimento económico. Essa é a contribuição da América do Sul na busca por uma vida digna, qualitativa.

O desenvolvimento é, sim, elemento indispensável à transformação dos ambientesnaturais e/ou artificiais -, contudo, jamais deve ser aceite como pressuposto de concentração de riquezas, de eliminação de seres vivos, de exploração desmedida da $n$ natureza, de apropriação dos saberes com fins lucrativos, da não difusão do conhecimento científico e tecnológico junto das nações em desenvolvimento. A América do Sul, nesse aspecto, e apesar de suas intensas adversidade, consegue ser um continente de extrema empatia com um tema que se refere ao mundo.

A imposição unilateral de uma vontade é prejudicial às políticas de inclusão social e integração dos povos com suas culturas e saberes. O imperativo da sustentabilidade visa uma relação legitimada pela solidariedade e comunhão, o que inibe a classificação de pessoas, povos e seres sem ordem de importância. A concepção herdada pela tradição andina do buen vivir representa o reconhecimento da natureza como "ser próprio", como parceira para que haja vida qualitativa para todos os seres que habitam o território terrestre.
No entanto, a leitura do texto esclarece como os objetivos de redistribuição das riquezas, de se efetivar uma justiça social mais forte, de emancipar os povos da América Latina podem ser desvirtuados, especialmente por programas governamentais, que não compreendem as raízes ancestrais do conhecimento proposto pelo buen vivir e dificultam mais ainda o cumprimento desses objetivos, a vida qualitativa elaborada pelo desenvolvimento sustentável uma "mentira existencial", ou seja, insiste-se nas economias predatórias e extrativistas, nas segregações sociais, no desrespeito à natureza.

A crise civilizatória ainda encontra significativos obstáculos para sua superação porque os governos tidos como progressistas, sociais, na América do Sul, estampam, em caráter publicitário, uma amálgama entre os princípios do buen vivir com os de uma economia europeia e/ou norte-americana. Em vez de se debruçarem sobre os caminhos possíveis orientados pela proposta de identidade histórica dos povos indígenas como alternativa para uma vida em plenitude, digna, na relação homem e mundo natural, prefere-se criar uma república dos bons sentimentos.

Por esse motivo, "viver bem" não significa "viver melhor". Trata-se de uma genuína postura de tolerância entre as culturas. $\mathrm{O}$ resgate daquilo que é comum a todos e forma sua unidade de identificação (comunidade) propõe essa saída dos domínios do "Eu" para, junto ao "Tu", constituir o "Nós". As terras sul-americanas são generosas o suficiente para prover as nossas necessidades, sejam culturais, naturais ou espirituais. O reconhecimento da Natureza como "ser próprio", como parceira na busca dessa melhoria na qualidade de vida para todos consolida a metamorfose na qual as dimensões política, jurídica e económica convergem esforços no sentido de elaborar um modelo de desenvolvimento sustentável para o continente já citado.

Sob esse nome, não é possível exaurir todas as potências criativas para tornar viável 
a pachasofia andina. Não se deseja constituir parâmetros delimitados para utilizar uma resposta universal a todas as dificuldades na América do Sul. Cada local tem suas características, as quais precisam ser compreendidas de modo indutivo, ou seja, por uma imersão microscópica nas raízes da vida andina. É a partir dessa condição que a busca pela "viver bem" se torna diferente porque as múltiplas cosmovisões são capazes de, igualmente, apresentarem outras proposições de desenvolvimento sustentável que não sejam enunciadas exclusivamente por um desejo de progresso desmedido.

Aparecem novas utopias carregadas de esperanças sensatas que nos previnem de uma postura excessivamente cética em relação ao nosso futuro comum. As evidências do nosso momento presente demonstram posturas contrárias à ditadura do capital e eficiência, bem como de governos que insistem em empregar significados propagandísticos em documentos nacionais ou planos de desenvolvimento sem haver qualquer preocupação com os modos de desenvolvimento da vida cotidiana.

A busca por políticas públicas que distribuem necessidades elementares sem agredir a natureza, a promoção de novos cuidados jurídicos e sensibilidades pelos ciclos de regeneração do mundo natural, a inclusão do estrangeiro, do campesino, do marginalizado pelas responsabilidades comunitárias, o reconhecimento da finitude de todas as matrizes energéticas evidenciam outro estágio de convivência, a qual necessita, ainda, de habitualidade para trazer outros momentos de proximidade e cumplicidade. Eis a América do Sul que mostra ao mundo novos horizontes, cujas raízes enaltecem vida digna em plenitude.

Desenvolvimento sustentável, a partir do buen vivir, não é um modelo, mas uma via compreensiva para descobrir significados (inclusive os óbvios) para garantir que nossa interdependência promova, cada vez mais, vida em plenitude para todos os seres vivos, sejam humanos ou não-humanos. Nessa linha de pensamento, a hipótese que se descreveu no início deste estudo demonstrou ser positiva no sentido de se constatar a insuficiência dos modelos de desenvolvimento sustentável para a América do Sul. O "viver bem" é a alternativa desejável para se buscar um progresso inclusivo, menos veloz, menos capitalizado e mais sensível no trato com todos os seres vivos.

\section{Notas}

1 “[...] É nesse contexto que emerge a ideia de Sumak Kawsay o Suma Qamaña: nasce na periferia social da periferia mundial e não contém os elementos enganosos do desenvolvimento convencional. Já não será questão de 'direito ao desenvolvimento' ou do principio desenvolmentista como guia da actuação do Estado. Agora trata-se do Buen Vivir das pessoas concretas, em situações concretas analisadas concretamente, e a ideia provém do vocabulário de povos de outrora totalmente marginados, excluídos da respeitabilidade e cuja língua era considerada inferior, inculta, incapaz do pensamento abstracto, primitiva. Agora o seu vocabulário entra em duas constituições" (tradução própria, Tortosa, 2009b, p. 2).

2 "La FEINE é uma organização não governamental dedicada ao desenvolvimento integral dos povos, comunidades e igrejas evangélicas indígenas do Ecuador. Um dos objetivos principais jornais da Federação é "coordenar com organismos internacionais públicos e privados, missões, instituições do Estado, organismos não governamentais e outras entidades para o desenvolvimento sustentável'; dentro das estratégias de ação estabelece a necessidade da 'formulação e proposta de políticas para o desenvolvimento integral dos povos indígenas"' (tradução própria, Tibán, 2014, p. 111-112). Na mesma linha de pensamento, a autora destaca como essas atitudes erodiram as : "[...] políticas integracionistas $\mathrm{e}$ homogeneizadoras do Estado com o objetivo de construir um país unicultural e unilíngue". (tradução própria, Tibán, 2010, p. 46). 
3 "Luis Macas, que foi presidente da CONAIE (Confederação de Nacionalidades Indígenas do Equador), fala do espaço comunitário, onde existe reciprocidade, convivência com a natureza, responsabilidade social, consenso, ou seja o 'Buen Vivir'" (tradução própria, Houtart, 2011, p. 2).

4 “[...] Por outra parte, Magdalena León a partir duma perspectiva feminista, introduz o conceito de 'economia do cuidado humano' [...] como expressão de Sumak Kawsay, porque ali se recupera a ideia de vida como eixo e categoria central da economia' [...]" (tradução própria, Houtart, 2011, p. 3).

5 "Todas as culturas têm uma forma de ver, sentir, perceber e projectar o mundo, o conjunto destas formas se conhece como Cosmovisão, ou Visão Cósmica. Os avôs e avós dos nossos povos ancestrais, fizeram florescer a cultura da vida inspirados na expressão do multiverso, onde tudo está ligado, interrelacionado, nada está fora, antes pelo contrário "tudo é parte de...; a harmonia e equilíbrio de um e do todo é importante para a comunidade. É assim que em grande parte dos povos da região andina de Colômbia, Equador, Bolivia, Perú, Chile e Argentina, e nos povos ancestrais (primeiras Nacões) da América do Norte persiste a Cosmovisão Ancestral ou Visão Cósmica, que é uma forma de compreender, de perceber o Mundo e manifestar-se nas relações de vida. "Existem muitas nações e culturas no Abya Yala, cada uma delas com suas próprias identidades, mas com uma essência comum: o paradigma comunitário baseado na vida em harmonia e o equilíbrio com o meio ambiente" (tradução própria, Huanacuni-Mamani, 2010, p. 27).

${ }^{6}$ Para Pasold, trata-se da "[...] base lógica da dinâmica da Pesquisa Científica que consiste em estabelecer uma formulação geral e, em seguida, buscar as partes do fenómeno de modo a sustentar a formulação geral". (tradução própria, Pasold, 2011, p. 205).
7 Segundo o mencionado autor: “[...] Técnica de investigação em livros, repertórios jurisprudenciais e coletâneas legais" (tradução própria, Pasold, 2011, p. 207).

${ }^{8}$ Nas palavras de Pasold: "[...] palavra ou expressão estratégica à elaboração e/ou expressão de uma ideia" (tradução própria, Pasold, 2011, p. 25). Grifos originais da obra em estudo.

${ }^{9}$ Reitera-se conforme Pasold (2011): “[...] uma definição para uma palavra ou expressão, com o desejo de que tal definição seja aceite para os efeitos das ideias que expomos [...]" (tradução própria, p. 37). Grifos originais da obra em estudo.

10 "O desenvolvimento sustentável é aquele que atende às necessidades do presente sem comprometer a possibilidade de as gerações futuras atenderem a suas próprias necessidades" (tradução própria, Nosso Futuro Comum, 1991, p. 46).

${ }^{11}$ Caracteriza-se como a lei da natureza que tende a reduzir as diferenças (pressão, temperatura, concentraçãoquímica, movimento) entre os fluxos energéticos fazendo com que os resíduos produzidos por essas interações sejam eliminados espontaneamente. Alcança-se o equilíbrio termodinâmico (Cechin, 2010, p. 69).

12 O caráter mediador da sophrosyne “[...] dá à areté grega um aspecto mais ou menos 'burguês': é a classe média que poderá desempenhar na cidade o papel moderador, estabelecendo um equilíbrio entre os extremos dos dois bordos: a minoria dos ricos que querem tudo conservar, a multidão das pessoas pobres que querem tudo obter" (tradução própria Vernant, 2008, p. 89/90). Apesar da visão proposta por Vernant, é Aristóteles (1999, par. 1107 a) que melhor descreve a perspectiva desta virtude, ao se rememorar o seu conteúdo como algo bom em si, ou seja, o meio termo entre o excesso e a deficiência o qual deve ser 
exercitado e compreendido com habitualidade: "A excelência moral, então, é uma disposição da alma relacionada com a escolha de ações e emoções, disposição esta consistente num meio termo [...] determinado pela razão [...]" (tradução própria, Aristóteles, 1999, par. 1106 b).

13 A expressão "salvar o planeta" é equivocada tanto no uso do substantivo "planeta" quanto do verbo "salvar". Na primeira hipótese, confunde-se a ideia de biosfera com planeta. $\mathrm{O}$ que se deseja proteger - permitir a continuidade dos diferentes ecossistemas no território terrestre - está num invólucro esférico abaixo da superfície: 160 quilómetros abaixo e outros 160 quilómetros para fora, na fronteira com o espaço, por meio dos oceanos e do ar (termosfera). Esse é o núcleo no qual permite a disseminação da vida em todo o globo. O verbo "salvar" também não pode ser traduzido como a condição de se eliminar a destruição desse lugar comum o qual todos os seres vivos habitam. "O mencionado verbo refere-se, conforme a leitura da obra de Veiga, no sentido de se evitar qualquer dano produzido pelas ações humanas" (tradução própria, Veiga, 2010, pp. 32/33).

14 "O movimento indígena do ponto de vista económico considera que o discurso atual de desenvolvimento é de curto prazo e que o neoliberalismo dominante não permite ao discurso oficial falar de outro tipo de desenvolvimento que não seja o capitalista. Argumenta que, em rigor, o discurso oficial não deveria de falar em desenvolvimento, mas sim de equilíbrios ou desequilíbrios macro-económicos, porque a questão central do desenvolvimento não está no significado do crescimento económico, mas no significado de um desenvolvimento humano integral e harmónico. Deste ponto de vista entende-se que a qualidade de vida deveria ser cada vez melhor a nível local e global. Por outro lado, acham importante considerar as políticas alternativas de desenvolvimento local e global, para ver se é possível iniciar um desenvolvimento de baixo para cima; concepção que justifica a iniciativa de começar conquistando os poderes locais nos sectores de população maioritariamente indígena, com o propósito de impulsionar propostas de desenvolvimento sustentável que abarque o económico, o social e o cultural, como uma concepção mais integral, mais harmónica e mais justa" (tradução própria, Tibán, 2014, p. 109).

15 "O desenvolvimento sustentável do ponto de vista dos indígenas dá ênfase principalmente ao crescimento económico e não se orienta para um desenvolvimento humano, cultural e ético de maneira mais integral. Contudo, de alguma maneira, os culturalistas e os eco-socialistas utilizam, podemos dizer assim, o conceito na base da cultura e da natureza respectivamente, para alcançarem um avanço em relação à proposta original e superar os aspectos negativos e a as críticas que o termo desenvolvimento sustentável gerou no seu início; no entanto é evidente pelo facto de não existir consciência, conhecimento e decisão dos atores sociais do desenvolvimento, é difícil que estas ideias dos culturalistas e eco-socialistas se tornem efectivas"(tradução própria, Tibán, 2014, p. 112).

16 Segundo Mancilla (tradução própria, 2012, p. 20): "[...] A redistribuição deve ser considerada como um processo e não como um fim em si mesmo, pois trata-se de um meio para conciliar a tensão entre as desigualdades do curto prazo e as transformações estruturais, distributivas do longo prazo. As mudanças estruturais requerem tempo pela sua própria complexidade. Apesar de que este seja o objetivo de um novo regime económico de acumulação, a dívida social acumulada é a essência da resposta, sem se poder esperar que obtenham os benefícios de uma mudança, mais estrutural. Esta dialéctica, entre necessidades de curto prazo e objetivos estruturais, tornou-se o foco fundamental da discussão na tomada de decisões na área da justiça distributiva. $\mathrm{O}$ imperativo do curto prazo reclama uma estratégia capaz de fazer política pública redistributiva, sem que esta coloque travão à transformação estrutural. 
A desigualdade e a pobreza sistémicas são fruto duma ordem económica concentradora de riqueza muito enraizada, acompanhada por um estado devedor (socialmente). É por isso que o papel do Estado se torna fundamental neste processo de redistribuição; a recuperação do público, reclassificando-o como um bem comum, e não como a soma de indivíduos; descorporativizando-o para evitar um sector público que privilegie interesses particulares; dirigindo, regulando e planificandoum novo regime de acumulação; e também redistribuindo das suas políticas tributárias e políticas se gastos sociais. O novo Estado deve deixar de ser Estado aparente para se converter num Estado integral [...], e jogar um novo papel de protagonista para garantir a justiça redistributiva; também pela via redistributiva de curto prazo".

17 "“[...] Agora também, o termo de 'suma qamaña' traduz-se como 'viver bem', mas não explica a grandeza do conceito. É melhor recorrer à tradução dos termos originais em ambas as línguas. Desde a Cosmovisão aymara, "do jaya mara aru1" o 'jaqi aru', 'suma qamaña' traduz-se da seguinte forma: - Suma: plenitude, sublime, excelente, magnifico, formoso. Qamaña: viver, conviver, estar sendo, ser estando. Então , a tradução que mais se aproxima de "suma qamaña" é 'vida em plenitude'. Actualmente traduz-se como "viver bem"” (tradução própria, Huanacuni-Mamani, 2010, p. 7).

18 “[...] Por outro lado, a tradução do kichwa ou quechua, (runa simi), é a seguinte: $\bullet \mathrm{Su}-$ mak: plenitude, sublime, excelente, magnífico, formoso (a), superior. - Kawsay: vida, ser estando, estar sendo. Vemos que a tradução é a mesma que em aymara: "vida em plenitude"” (tradução própria, Huanacuni-Mamani, 2010, p. 7).

19 "Pacha é uma palavra muito importante no Ser Andinopara compreender o mundo, é um termo com múltiplos significados. Segundo a tradução dos linguistas, faz referência não só ao tempo e ao espaço, mas para o ser Andino esta palavra vai para além do tempo e do espaço, implica uma forma de vida, uma forma de entender o Universo que supera o tempo-espaço (o aqui e o agora). Pacha não é só tempo e espaço, é a capacidade de participar activamente no multi-terminais, submergir-se e estar nele" (tradução própria, HuanacuniMamani, 2010, p. 71).

20 "Nossos antepassados compreendem que existem duas forças, a força cósmica que vem do céu; e a força telúrica, da Terra (a Pachamama). Estas duas forças convergentes no processo da vida, geram toda a forma de existência e as diferentes formas de existência relacionam-se através do AYNI (a complementaridade)" (tradução própria, Huanacuni-Mamani, 2010, p. 71).

21 "Os conceitos do bem viver põem em cheque todas essas ideias. Apresentam-se como um vínculo direto com os saberes tradicionais que estavam subordinados, questionam as transposições culturais e distanciam-se da ideia de desenvolvimento como crescimento económico. Em muitas cosmovisões indígenas não existe um conceito de desenvolvimento entendido como a concepção dum processo linear, como sucessão de estados anteriores e posteriores. Não se defende uma visão dum estado de subdesenvolvimento a ser superado, e tão- pouco de uma meta de "desenvolvimento" a ser alcançada, forçando a destruição das relações sociais e a harmonia com a natureza. Em vários casos não tem lugar a dicotomia ocidental que separa a sociedade da natureza. Tão-pouco há uma concepção de pobreza com carência de bens materiais ou uma riqueza entendida como sua abundância. Noutras palavras, o Bem Viver questiona a validez da própria ideia de progresso. A partir da Cosmovisão indígena, o melhoramento social- o seu desenvolvimento? -é uma categoria em permanente construção e reprodução. Nela está em jogo a vida mesmo" (tradução própria, Acosta \& Gudynas, 2011b, p. 104).

22 "Quando a expressão "um em todos, todos em um" não é visualizada pelo seu poten- 
cial integrador, no qual todos carregam a totalidade desse legado antropológico e biológico sul-americano, é improvável que haja o cumprimento desse objetivo desejado" (tradução própria, Aquino, 2014b, p. 428).

${ }^{23}$ Moraes e Freitas (2013) destacam os principais pontos de compreensão sobre a vida plena enfatizada pela proposta do buen vivir: “[...] 1. Priorizar a vida; 2. Obter acordos consensuais; 3. Respeitar as diferenças; 4. Viver em complementaridade; 5. Equilíbrio com a natureza; 6. Defender a identidade; 7. Aceitar as diferenças; 8. Priorizar direitos cósmicos; 9. Saber comer; 10. Saber beber; 11. Saber dançar; 12. Saber trabalhar; 13. Retomar o Abya Yala; 14. Reincorporar a agricultura; 15 . Saber se comunicar; 16. Controle social; 17. Trabalhar em reciprocidade; 18 . Não roubar e não mentir; 19. Proteger as sementes; 20. Respeitar a mulher; 21. Viver bem e NÃO viver melhor. 22. Recuperar recursos; 23. Exercer a soberania; 24. Aproveitar a água; 25. Escutar os anciãos" (p. 17) (tradução própria).

24 "O objetivo final de todo o tipo de todo tipo de "desenvolvimento" é o viver bem (allin o sumak kawsay; suma qamaña; ivi maräei; küme mogen). Este ideal inclui os outro seres, animais, plantas, minerais, astros, espíritos e divindades. O Viver Bem é um modo de existência que está em equilíbrio com todos os outros elementos da Pacha, de acordo com os princípios básicos da pachasofía andina, que são os princípios de relacionamento, complementaridade, correspondência, reciprocidade é ciclicidade. $\mathrm{O}$ viver bem não é riqueza nem pobreza, nem resíduos, nem escassez, nem luxo nem carência, mas sim uma vida em harmonia com todos os demais seres, uma convivência intercultural , interbiótica e intergeracional" (Estermann, 2012, p. 7) (tradução própria).

25 "Começada a segunda década do século XXI, vimo-nos envolvidos numa série de crises que pela primeira vez na história da humanidade se juntam de maneira explosivas catastrófi- ca, e que, além disso, graças à globalização dos mercados, dos meios de comunicação e a contaminação , mundializaram-se; crise financeira, crise económica, crise da dívida estatal, crise ecológica, crise alimentar, crise de valores, crise energética, crise militar e crise espiritual. Todos os indícios apontam para que já não se trata de uma crise entre outras, tal como foi a Grande Depressão dos anos de 1920, mas sim duma crise de modelo civilizacional que, depois de mais de quatrocentos anos de aparente superioridade, chega ao seu fim, numa decadência que se converte em decomposição vertiginosa aos olhos dos próprios e dos outros" (tradução própria, Estermann, 2012, p. 2).

26 "Quando outros sujeitos são reconhecidos como essenciais para a manutenção da vida, observa-se a insuficiência de um pacto cuja natureza é exclusivamente antropocêntrica. Nesse momento, surge a indagação: O Contrato Social é suficiente para preservar, também, o mundo natural caracterizado como 'ser próprio' junto aos seres humanos?" (tradução própria, Aquino, 2014a, p. 199).

27 Nas palavras de Zambam (tradução própria, 2012, p. 242): “[...] as múltiplas formas de participação [...] são decisivas para afirmar a importância da democracia na ação individual e coletiva das pessoas".

28 "Assim como a medicina moderna considera que o diagnóstico e o tratamento não podem estabelecer-se sem tomar em conta o enquadramento social do paciente, o Plano Nacional para o buen vivir não estaria capacitado para formular o diagnóstico e as políticas para atingir os seus objetivos se se abstrair do contexto económico internacional. A actual crise mundial causou uma recessão que ameaça converterse em crónica. Estados Unidos e União Europeia não conseguiram recuperar a prosperidade anterior, enquanto a América Latina - e com ela o Equador - fazem esforços para crescer, produzir e manter os empregos. Neste quadro vamos explicar a crise internacional de forma concreta e 
sucinta. Depois analisaremos os seus mecanismos de transmissão e finalmente, abordaremos as implicações e respostas que o Equador e a América Latina implantaram face a ela através do novo regionalismo latino-americano" (tradução própria, Equador, 2013, p. 42).

29 Maffesoli (2009, p. 43, tradução própria) adverte que o "[...] inferno está cheio de boas intenções [...]. E os bons sentimentos de um idealismo moral de fachada nada mais são que a falsa moeda de troca desse filosófico para o qual pouco importa o que é de fato a realidade em sua banal trivialidade. Do que não há dúvida é que é em nome desses idealismos (moral e filosófico) que se elaboram as técnicas da mentira mais apuradas".

30 Veja-se, por exemplo, as diferenças entre 2009 e 2013 referentes ao cumprimento do objetivo 7 enunciadas por Vega (2014), "se se faz uma comparação entre os objetivos propostos em 2009 e o alcançado em 2013 para garantir o Buen Vivir da natureza podese verificar que os resultados são bem mais escassos. Pode dizer-se que o Equador está perdendo a batalha perante a destruição do seu património florestal, e a perda da biodiversidade (alto número de espécies em extinção), e a contaminação médio-ambiental. Este balanço negativo aumenta se se analisarem dados sobre a perda de bosques nativos por causa da extensão da fronteira agrícola e da utilização de fogos florestais, a agressiva erosão que arrasta milhões de sedimentos para bacias do Pacífico e da Amazónia e ao aumento da vulnerabilidade dos eco-sistemas face às mudanças climáticas, que além disso põem em risco a disponibilidade de água necessária para implementar o avanço da produção hidroeléctrica de Energia" (tradução própria, p. 191).

31 " [...] o fato de experimentar em comum suscita valor, é vetor de criação. Que esta seja macroscópica ou minúscula, que ela se ligue aos modos de vida, à produção, ao ambiente, à própria comunicação, não faz diferença.
A potência coletiva cria uma obra de arte: a vida social em seu todo, e em suas diversas modalidades. É, portanto, a partir de uma arte generalizada que se pode compreender a estética como faculdade de sentir em comum" (tradução própria, Maffesoli, 2005, p. 28).

${ }^{32}$ Novamente, enfatiza Zambam (2014): "Atualmente, a proposição de políticas de desenvolvimento responsáveis, contextualizadas e integradoras das múltiplas áreas da existência humana e da sociedade precisa contemplar os valores, princípios e dinâmica da sustentabilidade empreendidos nos debates dos fóruns internacionais e na ampla rede de reflexão existente no mundo, assim como, na percepção e valorização das práticas que demonstram a possibilidade de efetivação de ideais que mobilizam líderes, personalidades e grupos expressivos da sociedade e alternativos ao modelo existente" (tradução própria, p. 161).

33 Moraes e Freitas (2013) destacam: "Cientistas e filósofos nórdicos há aproximadamente meio século vêm alertando sobre os perigos da continuidade do modelo parasitário predominante de relação entre os seres humanos e a natureza, com base na dominação, e, não na harmonia. Mas, é na América Latina, um continente em mudança, que desponta a coragem de fazer-se uma autêntica revolução paradigmática, com o giro ecocêntrico" (tradução própria, p. 17).

34 "Direito entende-se como a disciplina que se ocupa dos costumes, práticas e normas de conduta que a comunidade reconhece como vinculativas. A aplicação deste conjunto de normas corresponde à autoridade dentro da comunidade. Natural significa que esta disciplina emerge não somente das convenções sociais ou humanas, está sujeito intimamente às leis naturais e por consequência o social deve adequarse ao natural. Ancestral. Nossos antepassados viveram em harmonia e em equilíbrio, baseados nos princípios e leis naturais. Perante a modernidade que apresenta uma vida desligada da na- 
tureza, os povos indígenas propõem o retorno à vivência ancestral. Comunitário. O Ocidente entende comunidade como a unidade e estrutura social sómente humana; a Cosmovisão indígena originária entende a comunidade como a unidade e estrutura de vida, ou seja, tudo faz parte da comunidade, não sómente os humanos" (ênfase adicionada, Huanacuni-Mamani, 2010, p. 46-47).

35 “À ética imperativa da solidariedade sincrónica com a geração atual somou-se a solidariedade diacrónica com as gerações futuras e, para alguns, o postulado ético da responsabilidade para com o futuro de todas as espécies vivas na Terra" (tradução própria, Sachs, 2009, p. 49).

36 "A força, a autoridade e a superioridade moral do Viver Bem derivam, paradoxalmente, da tragédia dos povos originários da América Latina, os quais não obstante a sucessão de etnocídios de grande parte deles, do saque cultural sofrido e de memoricídios perpetrados durante cinco séculos de colonização, sobrevivem e, com eles a cultura da vida, pelo menos, entre aquelas comunidades indígenas que resistiram, mantendo em suas territorialidades uma relação harmónica com a natureza" (tradução própria, Moraes \& Freitas, 2013, p. 16).

37 "Esta Constituição, este é quiçá um dos seus maiores méritos, abre a porta para discutir o sentido histórico do desenvolvimento nacional. Estamos conscientes de que estas novas correntes d pensamento jurídico e político não estão isentas de conflitos. Ao abandonar o tradicional conceito da lei como fonte do direito, consolida-se a Constituição como ponto de partida jurídico independentemente das visões tradicionais. Não deve surpreendermo-nos, então, que esta nova carta magna gere conflitos com los jurisconsultos tradicionalistas, assim como com aquelas pessoas acostumadas a ter razão em função do seu pensamento (e sobretudo dos seus interesses). Não se trata simplesmente de fazer melhorado que se fez até agora. Como parte da construção colectiva de um novo pacto de convivência social e ambiental é necessário construir novos espaços de liberdade e romper todos as cercas que impedem a sua aplicação" (tradução própria, Acosta, 2010, p. 37).

38 "É claríssimo que em ambas as constituições a Terra assume a condição de pessoa, de forma expressa na equatoriana e tácita na boliviana, mas com iguais efeitos: qualquer um pode reclamar seus direitos, sem que se requeira que seja afetado pessoalmente, pressupondose que é um direito fundamental se se considera que é um direito exclusivo dos humanos. O sumak kawsay é uma expressão quechua que significa buen vivir ou pleno viver, cujo conteúdo não é outra coisa que a ética - não a moral individual — que deve reagir à acção do Estado conforme a que também devem relacionar-se as pessoas entre si e em especial com a natureza. Não se trata do tradicional bem comum reduzido ou limitado aos humanos, mas também ao bem de todo o vivente (prefere-se dizer hoje, respeito pela biodiversidade), incluindo por consequência os humanos, entre os quais se exige complementaridade e equilíbrio, não sendo alcançável individualmente" (Zaffaroni, 2010, pp. 120-121).

39 "As pessoas têm direito a um meio ambiente saudável, protegido e equilibrado. O exercício deste direito deve permitir aos indivíduos e coletividades das actuais e futuras gerações e dos outros seres vivos, desenvolveremse de forma normal e permanente".

40 "Qualquer pessoa, a título individual ou em representação de uma colectividade, está habilitada a propor acções legais em defesa do meio ambiente, sem prejuízo da obrigação de as instituições públicas actuarem obrigatoriamente face a atentados contra o meio ambiente".

41 " [...] Noutras palavras, o contrato social no qual se baseia a governabilidade da nossa sociedade deve ser complementado por um contrato natural" (Sachs, 2009, p. 49). 
42 "A proximidade do econcentrismo com a sustentabilidade ecológica é o caminho mais promissor para uma teoria funcional da justiça ecológica. [...] Para se tornar um conceito verdadeiramente ecológico, a justiça precisa chegar ao mundo não humano. [...] Não é o suficiente cuidar dos seres humanos que vivem hoje e amanhã, quando os processos naturais que sustentam a vida estão em risco. Há uma necessidade de identificar e reconhecer a importância ética e jurídica da integridade ecológica" (tradução própria, Bosselmann, 2015, p. 129).

43 "O reconhecimento dos Direitos da Natureza permite convertê-la em sujeito de direitos, valendo por si própria, independentemente da possível utilidade ou uso humano. Esta é uma postura biocêntrica, pelo que se deve assegurar a sobrevivência de espécies e ecossistemas. Isto não implica uma natureza intocada, mas que se aproveitem os recursos naturais mantendo-se os sistemas de vida" (Acosta \& Gudinas, 2011b, p. 108).

44 "A visão do viver melhor criou uma sociedade desigual, desequilibrada, predadora, consumista, individualista, insensibilizada, antropocêntrica e anti-natural. $\mathrm{O}$ viver melhor pressupõe um progresso ilimitados e leva-nos a uma competição uns com os outros para criar mais e mais condições para viver melhor. Contudo, para que alguns possam viver melhor, milhões e milhões têm e tiveram de viver mal. É a contradição capitalista" (tradução própria, Huanacuni-Mamani, 2010, p. 33).

${ }^{45} \mathrm{Na}$ concepção de Capella (1998) "Os cidadãos-servos são os sujeitos dos direitos sem poder. Da delegação no Estado e no mercado. Da privatização individualista. Os cidadãos se dobraram em servos ao ter dissolvido o seu poder, ao confiar só no Estado a tutela de seus 'direitos', ao tolerar uma democratização falsa e insuficiente que não impede o poder político privado modelar a 'vontade estatal', que facilita o crescimento, supra-estatal e extra-estatal, desse poder privado" (tradução própria, p. 147).
46 Sob o ângulo da filosofia política, a categoria designa um sistema " $[. .$.$] económico-$ social caracterizado pela liberdade dos agentes económicos - livre iniciativa, liberdade de contratar, propiciando o livre mercado - e pelo desenvolvimento dos meios de produção, sendo permitida a propriedade particular destes. Quem aciona os meios de produção (quem trabalha) em regra não os detêm". (tradução própria, Oliveira, 2010, p. 85).

47 “ “...] O plano reconhece que o Buen Vivir é uma reacção face a estilos de desenvolvimento neoliberais anteriores, e sustém que o "constrói continuamente a partir de reivindicações que procuram uma visão que supere as estreitas margens quantitativas do economicismo e que permita a aplicação de um novo paradigma cujo fim não seja o processo de acumulação material, mecanicista e interminável de bens, sem que se promova uma estratégia económica inclusiva, sustentável e democrática". Acrescenta a esses pilares o propósito de sair do antropocentrismo ocidental para criar outras relações com a natureza e a procura de igualdade, justiça social e valorização de outros saberes" (tradução própria, Acosta \& Gudinas, 2011b, p. 108).

48 "É preciso reconhecer que faltam bons indicadores e medidas para muitos destes componentes, mesmo se se recorre às visões 'institucionalistas'. Mas isso não significa que não sejam relevantes. Inclusivamente há razões para perguntar-se porquê a falta deles, ou a sua ausência seja, por sua vez, um indicador mais do funcionamento "mal desenvolvido" do sistema mundial contemporâneo. Saber o que é o Mau Viver, incluindo todas as necessidades básicas nos níveis descritos (sistema local, eco-sistema e sistema mundial), ajuda a definir o Buen Vivir e por onde se tem de começar a construí-lo: pelos mais débeis no sistema mundial e com um conteúdo bem distinto do "American Wth of lide" e dos meios normalmente utilizados para satisfazer os interesses das elites dos países dominantes e dos sucessivos países hegemónicos. Porque não se trata de "viver 
melhor" (melhor que outros, de maneira indefinida e sustentável) mas trata-se de se conhecer em que consiste esse Buen Vivir, individual, coletivo e planetário, alternativo ao Mau Viver que, é importante sublinha-lo, não chega a todo o Planeta da mesma maneira ". (Tortosa, 2009a, pp. 72-73).

49 “'O mercado por si só não é solução tãopouco o é o Estado. O subordinar o Estado ao mercado conduz a subordinar a sociedade às relações mercantilistas e à idolatria individualista. Livres duma economia subordinada pelas relações mercantilistas, o bem viver orientase por ligações dinâmicas e construtivas entre o mercado, a sociedade e o Estado. Procurase construir uma sociedade com diversidade de mercados, para não ter uma "sociedade de mercado", ou seja mercantilizada. Não se quer uma economia controlada por monopolistas e especuladores. Mas tão-pouco se reduz tudo ao Estado nem se promove uma visão estadista a ultranza da economia" (tradução própria, Acosta \& Gudinas, 2011a, p. 77).

50 "A economia, e, por conseguinte, o desenvolvimento económico, é para a pchasofia, andina a utilização prudente e cuidadosa da Casa Comum (wasi; uta) que é o universo (Pacha). O desenvolvimento económico que no Ocidente é sinónimo de crescimento e desenvolvimento sem mais, para o ser humano andino é parte integral de todo um processo holistico de melhoramento e maturação, ao ritmo medo desenvolvimento orgânico ("des-arrollo") da Pacha. Por tanto, o desenvolvimento económico está sempre sujeito a um processo maior que inclui aspectos espirituais, religiosos, culturais, civilizacionais, sociais e políticos. Na pratica, isto significa que a economia riem que submeter-se àpolitica $e$ à ética, e estas à Cosmovisão ou pachasofía". (tradução própria, Estermann, 2012, p. 8).

51 "'...] O homem é assim feito; interessase pelo que vai acontecer amanhã e não daqui a milhares de anos. E, no entanto, são as forças que atuam mais lentamente que são, em geral, as mais decisivas. A maior parte dos homens morre não de uma força que atua rapidamente - como uma pneumonia ou um acidente de viação - mas de ação lenta das forças que provocam o envelhecimento. Como fazia notar um filósofo jainista, é quando nasce que o homem começa a morrer". (tradução própria, Georgescu-Röegen, 2013, p. 63)

52 " [...] Basta que se entenda que o desenvolvimento deverá um dia prescindir do crescimento econômico. Além disso, a principal implicação atual dessa tese é que será muito melhor que o produto mundial aumente a uma taxa média de $2 \%$ - dobrando em trinta e cinco anos - do que de $7 \%$, quintuplicando em vinte e quatro. Mais: que essa média resulte de taxas das mais elevadas em uma centena de países periféricos e das mais baixas nas duas ou três dezenas de países centrais. Só isso poderá permitir que a qualidade do crescimento econômico seja compatível com a conservação ecossitêmica, gerando algo mais parecido com a tão almejada sustentabilidade"(tradução própria, Veiga, 2009, p. 49).

53 "Economia a partir da Cosmovisão dos povos originários, e em particular a partir da visão amara, é a forma em que os seres humanos e comunidade decidem relacionar-se com todas as formas de existência: animais, insectos, plantas, montanhas, rios, selva,ar, etc., que não são "recursos " mas seres que vivem e que merecem todo o respeito. Relacionam-se de forma complementar e recíproca. Por exemplo, as árvores geram oxigénio e absorvem anidrido carbónico. Os povos originários partem da consciência de que tudo está ligado e que pela sua natureza tudo tem um papel complementar; o ser humano é um criador e um cultivador por natureza, por conseguinte cuida, cria, semeia e colhe, tendo em conta o equilíbrio da vida. Que bens e serviços se produzirão, como serão.produzidos, como serão distribuídos e redistribuídos entre os membros da comunidade social e de vida (com outras formas de existência)" (tradução própria, HuanacuniMamani, 2010, p. 36).

54 "No ayllu não há lugar para o termo "recurso", já que se tudo vive, o que existe são seres 
e não objetos, e o ser humano não é o único parâmetro de vida nem é o rei da criação. O princípio ocidental procura dominar a natureza; a partir do princípio originário não se procura dominar nada, procura-se relacionarmo-nos debaixo do princípio e da consciência do ayni. Tão-pouco cabe o conceito de exploração de nada nem de ninguém, porque nada nem ninguém é útil só para um, nem o propósito das outras formas de existência são só para benefício do ser humano; tudo está numa relação de complementaridade, em perfeito equilíbrio (Ayni). Por consequência, tudo tem a sua importância; por exemplo as plantas produzem oxigénio e outros elementos para todos os seres, os insectos complementam-se com as sementes para os frutos, a chuva renova a vida de todos e o sol aquece para todos" (tradução própria, Huanacuni-Mamani, 2010, p. 35).

55 "Também é certo que o bem viver tem uma quota de romantismo, mas por outro lado oferece uma vigorosa dose de realismo. Recorde-se que os estilos de vida que propunham uma relação harmónica entre os seres humanos e destes com a natureza, com todas as limitações que se lhes possa apontar, foram a base para que as culturas indígenas pudessem resistir a mais de quinhentos anos de colonização e exploração" (tradução própria, Acosta \& Gudynas, 2011a, p. 81).

56 " [...] O ponto de contato entre sonho e vida, sem o qual o sonho produz apenas utopia abstrata e a vida, por seu turno, apenas trivialidade, apresenta-se na capacidade utópica colocada sobre os próprios pés, a qual está associada ao possível-real. [...] aqui teria lugar o conceito de utópico-concreto, apenas aparentemente paradoxal, ou seja, um antecipatório que não se confunde com o sonhar utópico abstrato, [...]" (tradução própria, Bloch, 2005, p. 145).

\section{Referências}

Acosta, A. (2013). El buen vivir: Sumak Kawsay, una oportunidade para imaginar otros mundos. Barcelona: Icaria.
Acosta, A., \& Gudynas, E. (2011a). El buen vivir: más allá del desarrollo. Revista Qué Hacer, 181, 71-81. Recuperado de http:// www.desco.org.pe/sites/default/files/quehacer_articulos/files/11_Gudynas_181. pdf

Acosta, A., \& Gudynas, E. (2011b). El buen vivir o la disolución de la idea del progreso. Em M. Rojas (Coord.), La medición del progreso y bienestar: propuestas desde América Latina (pp. 103-110). México: Foro Consultivo Científico y Tecnológico.

Aquino, S. R. F. (2014a). Do contrato social ao contrato natural: o tratado constitutivo da UNASUL como expressão de uma utopia concreta. Em: A. K. Trindade, A. A. Espíndola, \& S. O. Boff (Eds.). Direito, democracia e sustentabilidade: anuário do programa de pós-graduação stricto sensu da Faculdade Meridional (pp. 187213). Passo Fundo, (RS): IMED.

Aquino, S. R. F. (2014b). Por uma cidadania sul-americana: fundamentos para sua viabilidade na UNASUL por meio da ética, fraternidade, sustentabilidade e política jurídica. Saabrücken: Novas Edições Acadêmicas.

Aristóteles. (1999). Ética a nicômacos (3a ed., Trad. M. da Gama). Brasília: Editora da UNB.

Bloch, E. (2005). O princípio esperança (Trad. N. Schneider). Rio de Janeiro: EdUERJ; Contraponto.

Bosselmann, K. (2015). O princípio da sustentabilidade: transformando direito e governança (Trad. P. Gil). São Paulo: Editora Revista dos Tribunais.

Capella, J. R. (1998). Os cidadãos servos (L. R. de Andrade \& T. Correia Trad.). Porto Alegre: Sergio Antonio Fabris. 
Cechin, A. (2010). A natureza como limite da economia: a contribuição de Nicholas Georgescu-Roegen. São Paulo: SENAC/ EDUSP.

Estermann, J. (2012). Crisis civilizatoria y vivir bien: una crítica filosófica del modelo capitalista desde allin kawsay/ suma qamaña andino. Polis: Revista de la Universidad Bolivariana, 11(33), 1-22.

Galeano, E. (1999). Memórias de fogo: as caras $e$ as máscaras (Vol. 2). Porto Alegre: L\&PM.

Georgescu-Roegen, N.(2013). Odecrescimento: entropia, ecologia e economia (Trad. J. Duarte). Lisboa: Instituto Piaget.

Gudynas, E. (2014). Derechos de la naturaleza: ética biocéntrica y políticas ambientales. Lima: CLAES.

Houtart, F. (2011). El concepto de sumak kawsai (buen vivir) y su correspondencia con el bien común de la humanidad. ALAI, América en Movimiento. Recuperado de http://www.dhl.hegoa.ehu.es/ficheros/0000/0738/15._El_concepto_de_sumak _kawsai.pdf

Huanacuni-Mamani, F. (2010). Buen vivir/Vivir bien: Filosofia, políticas, estrategias $y$ experiencias regionales andinas. Peru: CAOI.

Maffesoli, M. (2005). A Transfiguração do Político: a tribalização do mundo (3a ed.). Porto Alegre: Sulina.

Maffesoli, M. (2009). A república dos bons sentimentos (Trad. A. Goldberger). São Paulo: Iluminura; Itaú Cultural.

Mancilla, A. S. (2012). La Equidad de la Economía: disputando la justicia distributiva. Em: A. S. Mancilla (Coord.),
iA (Re)distribuir! Ecuador para Todos (pp. 13-25). Quito: SENPLADES.

Moraes, G. O., \& Freitas, R. C. (2013). O novo constitucionalismo latino-americano e o giro egocêntrico dos andes: dos direitos de Pachamama e o Bem-viver na Constituição do Equador (Sumak Kawsay) e Bolívia (Suma Qamaña). Em: G. Moraes, \& R. Freitas. (Orgs.), UNASUL e o novo constitucionalismo latino-americano (pp. 11-27). Curitiba: CRV.

Nosso Futuro Comum (1991). Comissão Mundial sobre o Meio Ambiente $e$ Desenvolvimento (Relatório Brundtland, 2a ed.). Rio de Janeiro: Editora da Fundação Getúlio Vargas.

Oliveira, D. A. (2010). Capitalismo. Em V. Barreto (Coord.), Dicionário de filosofia política (pp. 85-89). São Leopoldo, (RS): Editora da UNISINOS.

Pasold, C. L. (2011). Metodologia da pesquisa jurídica: teoria e prática (12a ed.). São Paulo: Conceito Editorial.

República do Equador (2013). Plan Nacional de Desarrollo / Plan Nacional para el Buen Vivir 2013-2017. Quito: SENPLADES.

Sachs, I. (2009). Caminhos para o desenvolvimento sustentável. Rio de Janeiro: Garamond.

Tíbán, L. (2010). Estado Intercultural, Plurinacional y Derechos Colectivos en el Ecuador. Quito: Fundación Hanns Seidel.

Tíbán, L. (2014). El concepto del desarrollo sustentable y los pueblos indígenas. Em: A. Capitán, A. García, \& N. Guazha (Eds.), Sumak Kawsay Yuyay: Antología del pensamiento indigenista ecuatoriano sobre Sumak Kawsay. Huelva y Cuenca: FIUCUHU. 
Tortosa, J. M. (2009a). El futuro del maldesarrollo. OBETS. Revista de Ciencias Sociales, 4, 67-83.

Tortosa, J. M. (2009b). Sumak Kaway, suma qamaña, buen vivir. Recuperado de http://repositorionew.uasb.edu.ec/ bitstream/10644/2789/1/RAA-28\%20 Mar\%C3\%ADa\%20Tortosa\%2c\%20 Sumak\%20Kawasay\%2c\%20suma\%20 qama $\%$ C3\%B1a\%2c\%20buen\%20vivir. pdf

Vega, F. (2014). El Buen Vivir-Sumak Kawsay en la constitución y en el pnbv 2013-2017 del ecuadorobets. OBETS. Revista de Ciencias Sociales, 9(1), 167-194.

Veiga, J. E. (2009). Mundo em transe: do aquecimento global ao ecodesenvolvimento. Campinas, (SP): Armazém do Ipê.

Veiga, J. E. (2010). Desenvolvimento sustentável: o desafio do século XXI. Rio de Janeiro: Garamond.
Vernant, J. (2008). A origem do pensamento grego (17 ed., Trad. B. İsis-Borges). Rio de Janeiro: Difel.

Zaffaroni, E. R. (2010). La naturaleza como persona: Pachamama y Gaia. Neopanopticum, 109-132. Recuperado de http:// ia600309.us.archive.org/17/items/Zaffaroni-LaNaturalezaComoPersona.GaiaYPachamama/Zaffaroni-LaNaturalezaComoPersona.GaiaYPachamama.pdf

Zambam, N. J. (2012). Amartya Sen: liberdade, justiça e desenvolvimento sustentável. Passo Fundo: IMED.

Zambam, N. J. (2014). A democracia contemporânea: entre a cruz e a espada. Em: A. K. Trindade, A. A. Espíndola, \& S. O. Boff (Eds.), Direito, democracia e sustentabilidade: anuário do programa de pós-graduação stricto sensu da Faculdade Meridional (pp. 147-167). Passo Fundo, (RS): IMED. 